\title{
Introduction*
}

\section{Bengt Kriström}

I should like to begin by noting that the compilation of this book has been an easy task. Everyone we contacted in this matter was truly enthusiastic about the whole idea and vigorously supported it. It is quite common that a Festschrift is compiled by the students of the professor in question, and this is, to some extent, also true here. In one way or another, we are all Karl-Göran Mäler's students. His contributions have in many ways served to define the shoulders of knowledge on which we stand when exploring our subjects further. Paul Samuelson once said that the only coin worth having was the appreciation of one's peers. With Samuelson's currency, Mäler is a very rich man, indeed, not only because the coins come, so to speak, from social scientists but also, for example, from natural scientists.

Mäler's work has been a mainstay of the frontiers of environmental economics for more than three decades, in both a stock and a flow sense. This is a remarkable achievement in itself. I certainly wish I knew the secret behind this, besides the usual formula: to work hard and to have exceptional powers. But I think we need more than this. Richard Feynman, one of the outstanding scientists of the last century, once said:

'With more knowledge comes a deeper, more wonderful mystery, luring one on to penetrate deeper still. Never concerned that the answer may prove disappointing, with pleasure and confidence we turn over each new stone to find unimagined strangeness leading on to more wonderful questions and mysteries - certainly a great adventure!' (Feynman, 1988)

This kind of passion for exploring the unknown is, to me, a hallmark of the exceptional scientist.

\footnotetext{
Many of the chapters in this Festschrift were presented at the Karl-Göran Mäler Symposium, held in conjunction with the Environmental and Development Economics (EDE)-conference at the Royal Swedish Academy of Sciences, 6-8 September 2000. What follows are essentially the introductory remarks used to provide the setting for the book chapters. I acknowledge useful input from V. Kerry Smith and my co-editors. Because I did not include all their suggestions for changes, any remaining errors are my own.
} 


\section{BACKGROUND}

It is useful here to provide a brief summary of Mäler's background. His academic career began in 1958 with the study of mathematics at Stockholm University, and he obtained a BSc degree in 1962 (subjects studied included statistics, economics and political science). He did his military service in 1963 , and subsequently he was appointed junior lecturer at the Stockholm School of Economics in 1964. His Licentiate thesis on optimal growth was defended in 1968 (the Licentiate is a Swedish degree, somewhere between a Master's and a Doctorate. At that time, the requirements for a Licentiate thesis were probably more stringent than for a PhD today). In 1969, Erik Dahmén, in some ways the father of environmental economics in Sweden, and Assar Lindbeck, obtained a grant from the Riksbank foundation to do research in resource economics. This period also marked the beginning of Mäler's entry into environmental economics. A couple of years of intensive international activity followed. A Ford Foundation Grant enabled Mäler to visit the Massachusetts Institute of Technology and Stanford in 1969-70. A successful visit to Resources for the Future, Washington, DC, in 1971, included the completion of his thesis that autumn. The thesis was defended in 1973 and published in 1974 by Johns Hopkins University Press. It has long been out of print, but remains one of the classics of environmental economics. That same year, Mäler was promoted to associate professor at the Stockholm School of Economics, and to full professor the following year. In 1975 he was also a guest professor at the University of New Mexico. In 1989 he was a World Bank guest professor, and since 1991 he has been director at the Beijer Institute of Ecological Economics. Much more could be said about his background than has been included in this brief sketch, but a more detailed biography must be left to others. Here, we shall discuss some of his contributions.

\section{CONTRIBUTIONS}

\section{The General Equilibrium Perspective}

The general equilibrium perspective is one of the salient feature of Mäler's work. The thesis opens by putting the environment in the general equilibrium context, thereby providing a badly needed structure for the analysis of environment-economy interactions. Prior to Mäler's work, general equilibrium concerned the multiple interconnections between markets. His framework recognized that economic agents' activities generate impacts on the environment and there are feedback loops. That is, general equilibrium includes market and non-market interactions. Moreover, these non-market interactions 
prevent a competitive equilibrium from providing an efficient allocation of resources.

While the early work on general equilibrium theory was theoretical, the interest in applying it came early. His PhD student Lars Bergman presented an early application of computable general equilibrium modelling with environmental perspectives in 1977. Several later contributions have clear connections with the general equilibrium perspective. The pioneering work on resource accounting is obviously relevant here. Mäler's 1991 paper lays out an accounting system based on an intertemporal general equilibrium model.

The works on game theory, in particular the acid rain game, are also relevant here, since they are in some ways related to the ideas underlying equilibrium theory. In addition, interdisciplinary work with ecologists has always been motivated by exploring links between the economy and the environment; the pivotal idea which Mäler introduced in his 1974 book.

\section{The Weak Complementarity Idea}

In the autumn of 1969, watching a long-forgotten television programme somewhere in the United States, Mäler was contemplating an idea on valuation, put forward by Joe Stephens, concerning water quality and lake recreation (1966). The paper by Stephens was empirical. Mäler wanted to know under what conditions one could usefully infer something about the value of environmental quality, by looking at a related market for a private good, say travel expenditures. The conditions turn out to be a special form of complementarity between the private and the environmental good. Because it was not the standard strong sort of complementarity that was needed, the conditions were called 'weak complementarity'. The basis for this idea came from the duality methods that Peter Diamond was teaching, in 1969, in a now classic course on public finance. Franklin M. Fisher and Karl Shell use the same concept in discussing price indexes for quality change but miss the full significance of its revelation principles. The idea of weak complementarity is of extraordinary importance for empirical work. Hardly a day passes without some application of weak complementarity being made.

\section{Cooperation}

Mäler's attitude towards cooperation within and across sciences seems to have been borrowed from John Stuart Mill, who said that it was hardly possible to overrate the value of placing human beings in contact with persons dissimilar to themselves, or with modes of thought and action unlike those with which they were familiar and that such communication had always been one of the primary sources of progress. 
It is no surprise that the Beijer Institute of Ecological Economics is Mäler's brainchild, and that the continuing success of the institute is in no small measure a product of his belief in the value of cooperation in science.

\section{Teaching}

Mäler is an excellent teacher, perhaps with a more flexible attitude towards the role of schedules than most of us. In recent years, he has been deeply involved in capacity building in developing countries, by giving a series of short courses in various, invariably rather pleasant locations, around the developing world. This is an investment in human capital with potentially very high returns.

\section{CONCLUSION}

Most of us came to environmental economics because of a deep appreciation for environmental amenities. Nature in all its varied dimensions enriches our lives. When Mäler began his research in environmental economics, few would have believed that such amenities could have a place in the 'dismal science'. Within economics, beauty was found in the skill of the analyst in capturing the essential insights that stem from how choices respond to incentives. The honour of a Festschrift has, to this point, been limited to the finest of conventional economists - scholars such as Paul Samuelson. Indeed, at the Brown-Solow Festschrift party in honour of Samuelson it is reported that 'Franco Modigliani rose, pointed his finger towards Samuelson and said: "you ... have enriched our lives", Karl-Göran Mäler has shown how the beauty that enriches our everyday lives is an integral part of Samuelson's traditional economic analysis. Surely we are 'doubly enriched'.

\section{REFERENCES}

Feynman, Richard P. (1988), 'The Value of Science', in What do You Care What Other People Think: Further Adventures of a Curious Character, Ralph Leighton (ed.), New York: W.W. Norton \& Company, pp. 240-48.

Stevens, Joe (1966), 'Recreation benefits from water pollution control', Water Resources Research, 2, pp. 167-82. 